http://dx.doi.org/10.12775/szhf.2019.023

\author{
RAFA£ Michalski \\ Uniwersytet MikoŁaja Kopernika, Toruń, Polska \\ ORCID: 0000-0002-9587-5074 \\ E-MAIL: METASIS@UMK.PL
}

\title{
Antropologiczny zwrot w filozofii oświecenia - Johann Gottfried Herder
}

W artykule omawiam dwa zagadnienia związane z genezą XX-wiecznej antropologii filozoficznej. Pierwsze dotyczy pytania, czy i w jakim stopniu można uznać Johanna Gottfrieda Herdera za właściwego prekursora tej dyscypliny. Wątpliwość ta pojawia się w kontekście podkreślanej przez wielu badaczy opozycji, a wręcz sporu, między filozofią dziejów a antropologią na płaszczyźnie opisu ludzkiej rzeczywistości. Historycy idei wskazują jednomyślnie, że początków antropologii (i filozofii dziejów) należy poszukiwać w dobie oświecenia, a ściślej w drugiej połowie XVIII wieku. Najbardziej syntetyczne - a przy tym najczęściej cytowane w literaturze tematu - ujęcie tej problematyki przedstawia Odo Marquard w swojej pracy Schwierigkeiten mit der Geschichtsphilosophie ${ }^{1}$. Według niemieckiego badacza antropologię oświeceniową charakteryzowało,

${ }^{1}$ Odo Marquard, Schwierigkeiten mit der Geschichtsphilosophie (Frankfurt am Main: Suhrkamp, 1973). 
z jednej strony, porzucenie: a) „gnostyckich” roszczeń historiozofii zmierzającej do absolutyzacji człowieka jako podmiotu wolności i twórcy własnego losu, b) scjentyzmu krystalizujących się nauk przyrodniczych oraz c) poznawczych aspiracji klasycznej metafizyki. Z drugiej strony, wyróżniało ją ukierunkowanie badań na obszar świata życia codziennego (Lebenswelt) i naturę człowieka. W swoich analizach Marquard bardzo mało miejsca poświęca roli Herdera w procesie wyodrębniania się nowej dyscypliny filozoficznej. W artykule spróbuję pokazać, że pominięcie Herdera stanowi nie tylko małe przeoczenie w zasadniczo poprawnym opisie uwarunkowań ideowych, które doprowadziły do powstania antropologii filozoficznej, lecz oznacza zasadniczy błąd, który istotnie zniekształca obraz jej genezy.

Drugie zagadnienie wiąże się z tytułowym zwrotem antropologicznym, jakiego dokonał Herder w swoim dziele filozoficznym. Odniosę się tutaj głównie do najmniej znanej w Polsce wczesnej fazy twórczości autora Rozprawy o pochodzeniu języka. Głównym celem moich analiz będzie omówienie najważniejszych założeń Herderowskiego programu odnowy filozofii w duchu antropologii oraz wskazanie ich znaczenia dla późniejszego rozwoju antropologii filozoficznej.

\section{Geneza antropologii filozoficznej - ujęcie Odo Marquarda}

We wspomnianej już pracy Marquard poszukuje motywów, które zadecydowały o wyłonieniu się w drugiej połowie XVIII wieku zaczątków antropologii filozoficznej, a następnie doprowadziły do przekształcenia jej w odrębną dyscyplinę zgłaszającą roszczenia do statusu prima philosophia (XX wiek). Za pierwszy z tych motywów uznaje on odwrót filozofii od klasycznej metafizyki oraz od matematycznego przyrodoznawstwa, co pociągnęło za sobą zwrot ku światu życia (Lebenswelt). Zmiany te stały się możliwe dzięki filozofii Kanta, który paralelnie rozwijał swoją myśl krytyczną i antropologiczną. Różnicę pomiędzy filozofią, a w szczególności metafizyką przed- i pokantowską w jasny sposób opisuje w swojej pracy Mirosław Żelazny². Przed Kantem

\footnotetext{
${ }^{2}$ Por. Mirosław Żelazny, Idea wolności w filozofii Kanta (Wyd. Rolewski: Toruń, 2001).
} 
mianowicie, jak wyjaśnia autor pracy Idea wolności w filozofii Kanta, charakterystycznym zabiegiem było „oddzielanie refleksji nad istotą poznawanego świata od teorii poznania”. Dzięki filozofii Kanta teoria poznania stała się właściwym polem refleksji, w tym namysłu nad poznawanym światem (który - dodajmy - z antropologicznego punktu widzenia stanowi właśnie wspomniany świat życia) $)^{3}$ Trzeba również zauważyć, że sama perspektywa filozoficzna Kanta ma charakter wyraźnie antropocentryczny, co zaznacza się w formie stawianych przez niego pytań: „Co [ja, człowiek,] mogę poznać?”, „Co powinienem czynić?”, „Czego mogę się spodziewać?”. Królewiecki filozof poprzez swój analizujący rozumowe zdolności człowieka krytycyzm otworzył poniekąd horyzont badań nad rozumną naturą człowieka (z której m.in. wyrasta potrzeba metafizyki). Poniekąd, gdyż równocześnie zapoczątkował filozofię transcendentalną, która sytuowała się „obok” nauk empirycznych, w tym antropologii ${ }^{4}$.

Odpowiednio też, pisząc o „naturze ludzkiej”, Kant miał na myśli przede wszystkim tę sferę człowieka, która nie podlega przyrodniczemu opisowi, lecz stanowi podmiot moralny. Pomocna w dostępie do tej sfery miała być „antropologia w ujęciu pragmatycznym”, która - inaczej niż nauka o ludzkiej fizjologii - traktuje o tym, co człowiek, jako istota swobodnie działająca, może i co powinien z siebie uczynićs. Punktem wyjścia określonej w ten sposób antropologii był zaś obraz człowieka jako animal rationabile - zwierzę obdarzone władzą rozumu, „które może samo z siebie uczynić zwierzę rozumne", i tym samym jako istoty o dwoistej naturze: rozumnej i zmysłowej („zwierzęcej”) ${ }^{6}$. Kant, na co zwraca uwagę Marquard, antropologią nazywa również opartą na „Zwykłym doświadczeniu” „znajomość świata” (Weltkenntniss), w rozumieniu ludzkiego świata życia (Lebenswelt), który nie daje się zredukować ani do świata rozumowego (mundus intelligibillis), ani do świata

\footnotetext{
${ }^{3}$ Por. tamże, 14.

${ }^{4}$ Według Kanta, jak wyjaśnia w pewnym miejscu Żelazny, „konieczność świata natury nie może być $[. .$.$] wystarczającą podstawą wszystkiego i dlatego, zadając pewne pytania graniczne,$ rozum wkracza w sferę świata wolności, przeciwstawionego empirycznemu światu natury". (Por. tamże, 21).

${ }^{5}$ Por. Gernot Böhme, „Immanuela Kanta antropologia w ujęciu pragmatycznym”, w: Gernot Böhme, Antropologia filozoficzna. Ujęcie pragmatyczne, red. Stanisław Czerniak, tłum. Piotr Domański (Warszawa: IFIS PAN, 1998), 231-243.
}

${ }^{6}$ Cyt. za: tamże, 233. 
zmysłowego (mundus sensibillis) ${ }^{7}$. Wedle wyjaśnień Kanta ów świat to „»obcowanie $\mathrm{z}[\ldots]$ mieszkańcami miasta lub prowincji«, »podróżowanie«, »czytanie opisów podróży«, a w końcu »historia świata, biografie, a także sztuki teatralne i powieści «". Ujęcie to przekonuje wspomnianego autora do upatrywania w Kantowskiej antropologii świadectwa na to, iż zwrot ku światu życia miał doniosłe znaczenie dla genezy filozoficznej antropologii.

Zwrot ku światu życia można zaobserwować również w filozofii dziejów (reprezentowanej przez Johanna Gottlieba Fichtego i Georga Wilhelma Friedricha Hegla). W niej to rozważa się bądź „powołanie” człowieka rozumianego jako podmiot zmierzający w historycznym procesie życiowym do realizacji pewnego „ostatecznego celu” (wolności), bądź uwikłanie ludzkiego istnienia w rozwój rozumnego ducha. O tyle też filozofia dziejów tworzy zręby teorii historycznego świata życia. Klimat filozofii dziejów towarzyszy w pewnym sensie również myśli Kantowskiej. Kant snuje bowiem hipotezy o ciągłym procesie samodoskonalenia się człowieka, który jako istota swobodnie działająca uczestniczy w procesie realizacji „rozumności” - „wciąż nieziszczalnego celu, którego nie może osiągnąć jednostka, lecz co najwyżej gatunek"10. Jak wiadomo, ostatecznym celem rozwoju dziejów ma być związek narodów żyjących w stanie wiecznego pokoju. Zgodnie z filozofią Hegla antropologia miała stanowić część teorii ducha subiektywnego. Duch miał być $\mathrm{w}$ niej rozpatrywany na swoim najniższym poziomie - jako duch naturalny. Przedmiotem antropologii miała być odpowiednio analiza rozwoju „duszy naturalnej” (jaźniowej komórki ducha pojawiającej się w przyrodzie), jeszcze nie świadomej, a jedynie „odczuwającej”; duszy jako mocy kształtującej ciało i podtrzymującej jego biologiczne funkcje ${ }^{11}$. Marquard zauważa, że rozumiana w ten sposób antropologia nie mogła wystarczać do uzyskania „całościowej” wiedzy o człowieku, jako wiedza o duchu samym w sobie

\footnotetext{
${ }^{7}$ Por. Odo Marquard, Schwierigkeiten, 212-213.

${ }^{8}$ Tamże, 213.

${ }^{9}$ Por. Elżbieta Paczkowska-Łagowska, Logos życia. Filozofia hermeneutyczna $w$ kręgu Wilhelma Diltheya (Gdańsk: Słowo/obraz terytoria, 2000), 41-45.

${ }^{10}$ Cyt. za: Böhme, „Antropologia w ujęciu pragmatycznym”, s. 233.

${ }^{11}$ Uwagi na temat Heglowskiej antropologii opierają się na pracy: Mirosław Żelazny, Heglowska filozofia ducha (Toruń: Wydawnictwo Naukowe UMK, 2000).
} 
zasadniczo bowiem nie odpowiadała na pytania związane z zagadnieniem konkretnych historycznych „urzeczywistnień” samego człowieka ${ }^{12}$.

Wyzwolenie z kontekstu filozofii dziejów antropologia zawdzięcza tej odmianie niemieckiego idealizmu, która odmówiła historii celowości jej rozwoju. Procesowi detronizacji historii - w którym zasadniczy udział miał Friedrich Wilhelm Schelling, jako główny wyraziciel ducha niemieckiego romantyzmu - towarzyszyło uznanie "natury” za jedyne źródło człowieczeństwa ${ }^{13}$. Natura pojmowana była przy tym oczywiście nie w znaczeniu essentia ani jako przedmiot matematycznego przyrodoznawstwa, lecz w sensie „przyrody": organicznej, żywej, uduchowionej całości. Właśnie zwrot ku filozofii przyrody Marquard uznaje za drugi, po zwrocie ku filozofii świata życia, charakterystyczny rys rozwoju antropologicznego myślenia. Obok antropologii w ujęciu pragmatycznym pojawiła się teraz antropologia „fizjologiczna”, która pyta o to, co natura uczyniła z człowieka. W ten sposób antropologia stała się postacią filozofii natury (przyrody) - jako filozofia natury człowieka. Tym samym awansowała również do roli filozofii fundamentalnej, lokując się jako opozycja i alternatywa w stosunku do uniwersalnej filozofii dziejów: jako filozofia "natury” poszukuje ona bowiem stałych i opornych na przemiany właściwości człowieka, stroniąc od teorii postępu i doskonalenia się ludzkości, w których idea „człowieczeństwa” poświęcana jest w imię idei „ludzkości”.

Zrekonstruowane powyżej ujęcie Marquarda operuje przejaskrawioną opozycją antropologii i filozofii dziejów i być może właśnie z tego powodu niemiecki filozof pomija w swoich analizach postać Herdera. Jak pokażę w dalszych wywodach, dla autora Rozprawy o pochodzeniu języka nie istnieje żadna sprzeczność w łączeniu wizji historiozoficznej z analizami antropologicznymi. Człowiek jest dla niego istotą dziejową, podlegającą nieustannym metamorfozom, dlatego może odkryć sens istnienia jedynie wówczas, gdy zrozumie swoje uwikłanie w żywioł historii. Sama dziejowość wyrasta nato-

\footnotetext{
12 Por. Odo Marquard, Schwierigkeiten, 217.

${ }^{13}$ Marquard w kontekście rozważań nad filozofią historii pisze w jednym z artykułów: „Dla mnie [...] paradygmatycznym zabiegiem jest podjęta przez Schellinga po roku 1797 próba uzdrowienia historii przez świętość natury, która przez romantyzm usankcjonowana została jako lepsza historia”. Odo Marquard, Apologia przypadkowości, tłum. Krystyna Krzemieniowa (Warszawa: Terminus 1994), 59.
} 
miast z nieustabilizowanej, wybrakowanej natury człowieka, która zmusza go do samodzielnego kształtowania warunków umożliwiających przeżycie w zmiennym, nie zawsze przyjaznym środowisku. Tytuł niedokończonego opus magnum Herdera Myśli o filozofii dziejów sugeruje, że jego koncepcję należałoby zaliczyć raczej do historiozofii aniżeli do antropologii filozoficznej, jednakże wrażenie to okazuje się mylące. Filozof ukazuje bowiem historię ludzkości na tle świata roślin i zwierząt, w tym ewolucji materii nieożywionej. Dzieje kultury człowieka stają się u niego w znacznej mierze historią zoologiczną i geograficzną. W dziele tym znajdujemy m.in. stwierdzenie, że ludzka istota $\mathrm{w}$ tej mierze, $\mathrm{w}$ jakiej jej życie jest wegetacją, dzieli los roślin ${ }^{14}$. Filozof zwraca uwagę na pokrewieństwo budowy zwierząt i człowieka, zwłaszcza budowy kości, zauważa też zaskakujące podobieństwo budowy mózgu homo sapiens i naczelnych. Znamienne dla Herderowskiej koncepcji jest przy tym krzyżowanie się dwóch perspektyw opisu człowieka, tj. kulturalistycznej i naturalistycznej. Z jednej strony filozof podkreśla, że monopole kulturowe człowieka, jak wychowanie przez sztukę i historię, wiążą się nieodmiennie $\mathrm{z}$ językiem, $\mathrm{z}$ drugiej zaś strony uwzględnia jego organo-biologiczne uposażenie. Rozpatruje m.in. skutki wyprostowanego chodu, który pozwala homo sapiens uwolnić ręce, a tym samym subtelniej rozwinąć zmysł dotyku, dzięki czemu nabywa on umiejętności budowania i projektowania narzędzi ${ }^{15}$. Najważniejszym instrumentem rozwoju gatunku ludzkiego obok wyprostowanej postawy, mózgu i sprawnej ręki jest dla Herdera język: „Tylko dzięki mowie oko i ucho, a nawet wrażenia wszystkich zmysłów kojarzą się w jedno i tylko dzięki niej jednoczą się one w myśl twórczą" ${ }^{\text {"16 }}$. Język uznany za główny monopol człowieka odpowiada za rozwój kultury, ale jego korzenie wyrastają z biologicznego podłoża.

Już we wczesnej Rozprawie o pochodzeniu języka Herder inicjuje antropologiczną refleksję nad językiem ${ }^{17}$. Problem genezy ludzkiej mowy próbuje bo-

\footnotetext{
${ }^{14}$ Johann Gottfried Herder, Myśli o filozofii dziejów, tłum. Józef Gałecki, t. 1 (Warszawa: PWN, 1962), 61.

15 Tamże, 125.

16 Tamże, 157.

${ }^{17}$ Johann Gottfried Herder, Rozprawa o pochodzeniu języka, tłum. Barbara Płaczkowska, w: Johann Gottfried Herder, Wybór pism (Wrocław: Zakład Narodowy im. Ossolińskich, 1987), 59-175.
} 
wiem rozwiązać, wychodząc od biologicznych uwarunkowań homo sapiens. Z czysto antropologicznej perspektywy człowiek jawi się jako istota nacechowana brakiem (Mängelwesen) - w przeciwieństwie do większości zwierząt nie posiada wyspecjalizowanych instynktów i organów zmysłowych, a ponadto nie jest osadzony w określonym, zaspokajającym jego potrzeby „kręgu środowiska" ${ }^{18}$. Herder przeprowadza w tym dziele dedukcję mowy z jakościowych cech zmysłów i uzupełnia ją wskazaniem na ogólne prawidłowości rozwoju człowieka. Najważniejszą z nich jest zasada „ekonomii natury”, zgodnie z którą człowiek jako „istota ułomna” kompensuje swój deficyt biologiczny, używając rozumu i języka. Język okazuje się nieodzownym instrumentem $\mathrm{w}$ procesach artykulacji i organizacji potrzeb, stanowi ponadto idealne medium, które kumuluje ludzkie doświadczenie i wspiera człowieka w opanowywaniu przyrody.

\section{Kryzys i odnowa filozofii}

Młody Herder, uczeń przedkrytycznego Kanta, reaguje z wrażliwością sejsmografu na symptomy rozkładu życia akademickiego, w jakim przyszło mu dojrzewać i stawiać pierwsze kroki na drodze pisarskiej kariery. Intelektualna atmosfera panująca w tamtych czasach pod wieloma względami przypominała współczesną aurę kryzysu nauk humanistycznych, którego przejawem jest choćby tocząca się od wielu lat debata nad ich legitymizacją ${ }^{19}$. Połowa XVIII wieku to czas rozkwitu nauk przyrodniczych (fizyki, medycyny, fizjologii, zoologii) i matematyki. Herder zmaga się w tym czasie z podobnymi dylematami jak my dzisiaj. Streszcza je podstawowe pytanie: jak uzasadnić rację istnienia filozofii, zachować jej autonomię i rangę wobec postępu nauk ścisłych? Już jako początkujący myśliciel Herder dochodzi do wniosku, że filozofia potrzebuje odnowy, zmiany swojego paradygmatu. W tekście z 1765 roku Jak filozofia może stać się bardziej powszechna i użyteczna

\footnotetext{
${ }^{18}$ Herder antycypował koncepcję „wokół-świata” Jakoba von Uexkülla. Por. Istota żywa jako podmiot: Wybór pism Jakoba Johannesa von Uexkülla, red. Aldona Pobojewska (Łódź: Studio Wydawnicze KARTA, 1998).

${ }^{19}$ Por. Paweł Markowski, Polityka wrażliwości (Kraków: Universitas, 2013).
} 
dla pożytku ludzi (będącym odpowiedzią na pytanie zadane przez Akademię Berneńską: czy prawda filozofii może być użyteczna? $)^{20}$ Herder porównuje ówczesny sposób uprawiania filozofii z modelami innych typów wiedzy i postuluje, aby filozofowie wyciągnęli wnioski z tego porównania i dokonali krytycznej autorefleksji. Według niego podstawowym błędem filozofii jest jej odwrócenie się od praktyki, od świata przeżywanego, jakbyśmy dzisiaj powiedzieli. To odcięcie się od „ludzkich spraw” prowadzi do jałowego formalizmu, stworzenia autonomicznej i autarkicznej dziedziny rozważań oderwanych od życia i czysto spekulatywnych scholastycznych ćwiczeń, które nie znajdują żadnego społecznego odzewu. Według Herdera istnieje ścisła zależność pomiędzy eskapizmem urzędującej na uniwersytetach filozofii a stanem powszechnej ignorancji społeczeństwa. Niewyedukowani obywatele nie posiadają odpowiednich instrumentów do obalenia filozoficznych idoli (Heiligtümer der Weltweisheit) i przywrócenia zdrowego rozsądku w sferze publicznej. Odcięcie się filozofii od aktualnych problemów stwarza więc nieuchronnie niebezpieczeństwo powrotu do barbarzyństwa ${ }^{21}$. Zwrot ku praktyce społeczno-politycznej nie może bynajmniej oznaczać porzucenia autonomii filozofii, która reprezentuje najwyższy poziom rozwoju ludzkiego umysłu ${ }^{22}$. Antycypując Freudowską teorię kultury, Herder podkreśla, że osiągnięcie tego stanu wymaga od filozofów stałego wyrzeczenia, ofiary i dyscypliny. Dlatego praktyczna część odnowionej filozofii musi zachować „swoją abstrakcyjną część [...] w nienaruszonym i nieuszkodzonym stanie”23, musi zatem zachować swoją suwerenność.

Perfekcjonistyczne poszukiwanie prawdy i niepodważalnych uniwersalnych zasad powoduje, że filozofowie tracą grunt pod nogami i wypuszczają w swoich gabinetach sterylne, oczyszczone z "brudu” empirii pojęciowe bańki. Dla niego samego cyzelowanie technik abstrakcyjnego myślenia pozbawia światłą publiczność narzędzi, które mogłyby pomóc jej zrozumieć otaczający świat i uzyskać dojrzałość intelektualną. W murach akademii roz-

\footnotetext{
${ }^{20}$ Johann Gottfried Herder, Wie die Philosophie zum Besten des Volks allgemeiner und nützlicher werden kann, w: Johann Gottfried, Werke, t. 1, Frühe Schriften, 1764-1772 (Frankfurt am Main: Dt. Klassiker Verlag, 1985), 101-134.

${ }^{21}$ Tamże, 121.

22 Tamże, 123.

${ }^{23}$ Tamże, 122.
} 
wija się frenetyczna walka o uznanie, będąca wyrazem próżności uczonych oraz jałowej potrzeby poszukiwania nowości intelektualnych, które mogą przynieść im chwilową sławę ${ }^{24}$ Herder piętnuje w szczególności panujący wówczas pogląd, że logika dostarcza najważniejszych norm dla filozoficznej refleksji. Prymat logiki przyczynia się do formalizacji filozofii, podczas gdy filozofia powinna uczyć samodzielnego myślenia. Weimarski myśliciel proponuje wprowadzenie nowej praktyki filozofowania, która uwzględniałaby ludzkie, egzystencjalne potrzeby. Aby dokonać takiej wolty, należy jednak najpierw wyedukować samych filozofów. Filozofia powinna zachować swoją względną autonomię, jednakże nie może unikać interdyscyplinarności, szukania inspiracji w innych dziedzinach nauk. Musi przede wszystkim na nowo znaleźć swoje miejsce w społeczeństwie, dostarczać mu adekwatnych form ekspresji i promować samodzielne krytyczne myślenie. Bez niego zanika wewnętrzna wolność, a człowiek popada w konformizm. Pasywna wiara w autorytet przeobraża się bowiem nieuchronnie w stan wewnętrznej tyranii. Filozofia powinna nastawić się na zwalczanie przesądów i wydobywanie ludzi ze stanu intelektualnej bierności. Tylko w ten sposób może przyczynić się do rozwoju świadomości obywatelskiej, której promień odpowiedzialności wykracza poza krąg partykularnych interesów i obejmuje dobro publiczne. Cel filozofii nie jest więc czysto teoretyczny, ale zawiera implikacje praktyczne. Używając słów Kanta, można powiedzieć, że filozofia winna wyprowadzić człowieka z zawinionej przez siebie niedojrzałości.

Najważniejszym punktem proponowanej przez Herdera zmiany orientacji filozofowania jest postulat antropologicznej refleksji nad ludzką kondycją. Nowa zorientowana na człowieka filozofia powinna stać się swoistą forpocztą całego systemu edukacyjnego, dając wskazówki, w jakim kierunku należy kształtować człowieczeństwo (Humanität) oraz wychowywać świadomych swoich praw i obowiązków, dojrzałych obywateli. Herder podkreśla wagę zakorzenienia człowieka w konkretnej tradycji, środowisku i wspólnocie językowej, dlatego postuluje, aby wprowadzić języki narodowe do systemu powszechnego nauczania, a tym samym znieść prymat łaciny i francuskiego w edukacji. Powszechność edukacji oznacza dla niego również konieczność dopuszczenia kobiet do nauki uniwersyteckiej.

${ }^{24}$ Tamże, 109. 
Główny deficyt ówczesnego systemu kształcenia wynika, jego zdaniem, z abstrakcyjnego dualizmu rozumu i zmysłowości (a więc również emocji i afektów). Szkoła winna angażować całość psychofizyczną człowieka, a nie przekazywać mu jedynie abstrakcyjne treści. Zaniedbując zmysłowo-empiryczny wymiar człowieka, filozofowie negują w istocie własne człowieczeństwo. Filozofia musi zatem zstąpić z rozgwieżdżonego nieba spekulacji do ludzkich domów i zastąpić wyrafinowane analizy kwestii epistemologicznych (sprowadzających się wówczas do sporu między empirystami i racjonalistami) badaniem możliwie szerokiego spektrum ekspresji człowieczeństwa, powinna zatem stać się czymś w rodzaju Weltweisheit („mądrości świata”) opartej na znajomości innych kultur, ich historii, systemów wartości, a wreszcie wiedzy pochodzącej z nauk empirycznych, psychologii, fizjologii, geografii etc. Odnowiona filozofia ma skupiać się jednak nie tyle na wynikach swoich dociekań, ile na samej praktyce kształcenia (Bildung). Herder przypisuje więc sobie rolę terapeuty osłabionej i przyczyniającej się do kulturowego kryzysu filozofii wiedzącego, jak przekształcić ją w „antidotum”25 i przywrócić jej status nauki użytecznej dla dobra publicznego. Uzdrowienie filozofii sprowadza się w ostatecznym rozrachunku do „włączenia” (Einziehung) jej do antropologii ${ }^{26}$.

\section{Ku nowej metafizyce - antropologiczny zwrot w filozofii}

Sceptycyzm Herdera wobec tzw. szkolnej metafizyki wynikał w znacznej mierze z rozkwitu nauk biologicznych - zwłaszcza fizjologii - które podważały wiele standardowych przesłanek filozoficznych i otwierały nowe perspektywy badawcze. Szczególne znaczenie w Niemczech miała w tym kontekście praca Ernsta Platera z 1772 roku zatytułowana Anthropologie für Aerzte und Weltweise, która wywarła duży wpływ na Herdera, a także Fryderyka Schillera. Jako uznany fizjolog i filozof przyrody o proweniencji lebnizjańskiej był on krytycznie nastawiony wobec filozofii Kanta i stał się prekursorem współ-

\footnotetext{
25 Tamże, 122.

26 Tamże, 132.
} 
czesnej antropologii. Dla zmiany klimatu intelektualnego w Niemczech znaczenie miała również intensywna recepcja filozofii Davida Hume’a i Jean-Jacques'a Rousseau. Zmiana ta nie polegała bynajmniej na budowaniu prostej opozycji metafizyka - antropologia, lecz zasadzała się na podejmowanych $\mathrm{z}$ różnych stron próbach przeformułowania metafizyki w nowym duchu. Już w swoim pierwszym tekście Versuch über das $\operatorname{Sein}^{27}$ dedykowanym Kantowi młody Herder próbował wskazać możliwość stworzenia nowej metafizyki opartej na fundamentach antropologicznych. Zaznaczyły się w niej zarówno wpływy Spinozjańskiej koncepcji życia, jak i wysiłek skonstruowania antropologicznie ufundowanej metafizyki. Rozwinięcie tych idei znajdziemy natomiast we wspomnianym konkursowym tekście Wie die Philosophie zum Besten des Volks allgemeiner und nützlicher werden kann z 1765 roku.

W Eseju o bycie Herder próbuje przekształcić kwestie epistemologiczne w pytania psychologiczne i na tej podstawie stworzyć podwaliny własnej „podmiotowej filozofii” ${ }^{28}$. W duchu Hume’a stwierdza, że na podstawie doświadczenia nie możemy nic powiedzieć na temat rejestrowanych przez nasze zmysły przyczyn reprezentacji świata zewnętrznego. Nie można tego stwierdzić ani w stanowiskach empirystycznych, ani idealistycznych, ponieważ nie wiemy, czy przyczyna ta tkwi w obiektywnie istniejących rzeczach, czy też w spontanicznej aktywności umysłu ${ }^{29}$. Idąc śladem Kantowskiej psychologii wiedzy z wczesnych lat 60 . XVII wieku, podkreśla ponadto, że zwierzęta w przeciwieństwie do ludzi nie odróżniają reprezentacji ukazujących właściwości zewnętrznych obiektów od tych, które wskazują na wewnętrzne stany umysłu $^{30}$. Dalej przyjmuje, że specyficzny tylko dla ludzi zmysł wewnętrzny opiera się na zdolności spontanicznego wytwarzania przedstawień. Jedynie człowiek może powiedzieć „ja jestem”31. Ale może to powiedzieć, a zatem uzyskać samoświadomość tylko wtedy, gdy wcześniej otrzyma mgliste przedstawienia od zmysłów zewnętrznych. Ostatecznym źródłem wszystkich przedstawień są zatem zmysły zewnętrzne, tutaj Herder zgadza się z Johnem Lockiem. Epistemologiczne kwestie nabierają w tym kontekście znaczenia

\footnotetext{
${ }^{27}$ Herder, Versuch über Sein w: tenże, Werke, 9-29.

28 Tamże, 20.

29 Tamże, 10.

${ }^{30}$ Tamże, 11.

31 Tamże.
} 
psychologicznego. Człowiek obdarzony zarówno zmysłem wewnętrznym (niekształtującym przedstawień, a tylko je porządkującym), jak i zmysłami zewnętrznymi (wytwarzającym reprezentacje) może być analizowany pod kątem genezy tychże przedstawień. Psychologiczne analizy prowadzą zaś Herdera do tezy, że zmysłowość jest nie tylko źródłem przedstawień, ale również stanowi ich konceptualne zwieńczenie. Myślenie oparte na pojęciach wywodzi się z mgławicowych wrażeń, jego korzenie sięgają zatem sensualnego podłoża. Herder przekonuje, że analiza, drobiazgowy rozbiór pojęć nie dociera wcale do czystych intelligibilnych konstrukcji, lecz napotyka niepoddające się dalszej analizie elementy zmysłowości ${ }^{32}$. Krytyka racjonalistycznej metafizyki staje się dla Herdera podstawą projektu „subiektywnej filozofii”, która powinna wskazać porządek fundamentalnych, zmysłowych pojęć filozoficznych leżących u podłoża wszystkich operacji poznawczych. Pojęcia te nie mają charakteru obiektywnego, lecz subiektywny właśnie, ponieważ stanowią efekt aktywności zmysłowego podmiotu, który nie ma bezpośredniego dostępu do zewnętrznego świata ani nie wytwarza czysto intelligibilnej sfery myślenia. Herder podkreśla, że te zasadnicze schematy poznawcze z trudem poddają się analizie i nie można obiektywnie uzasadnić ich ważności, ale posiadają cechę pewności, która pod tym względem zbliża je do instynktu. Podstawą wszystkich nieanalizowalnych pojęć jest pojęcie bytu - najbardziej zmysłowa kategoria fundująca wszystkie inne pojęcia łącznie z pojęciami czasu, przestrzeni i siły. Za Christianem Augustem Crusiusem powtarza, że ludzki podmiot nie jest zdolny wytworzyć czysto racjonalnej wiedzy, która opierałaby się wyłącznie na formalnej zasadzie sprzeczności i racji dostatecznej. Każda wiedza potrzebuje jakiejś zasady materialnej ${ }^{33}$. Dla Herdera taką zasadą jest właśnie pojęcie bytu, które odsyła do operacji umysłu ustanawiającej przedstawieniową treść jako coś istniejącego.

Założenia subiektywnej psychologii otwierają przed niemieckim myślicielem perspektywę holistycznego idealistycznego sensualizmu, który obejmuje zarówno Boga, jak i ludzką egzystencję. W tej metafizycznej wizji boski rozum stanowi zasadę bytu każdej istniejącej rzeczy będącej przejawem boskiej myśli. Sensualizm Herdera nie odrzuca więc - w przeciwieństwie do francu-

\footnotetext{
32 Tamże.

33 Tamże, 20.
} 
skiego sensualizmu - ani metafizyki, ani teologii. Człowiek jest istotą zmysłową, która partycypuje w boskim porządku. Skończony ludzki rozum może jednak zrekonstruować część tego porządku, opierając się na doświadczeniu.

W rozprawie Jak filozofia może stać się bardziej powszechna i użyteczna dla pożytku ludzi Herder poddaje analizie główne typy krytyki filozofii. Z jednej strony takie dyscypliny jak matematyka i fizyka podważają samą zasadność roszczenia filozofii do prawdy, z drugiej zaś teologia (mieniąca się przyjaciółką Boga) i polityka (mieniąca się przyjaciółką ludzkości) krytykują filozofię z uwagi na cele leżące poza zakresem jej badań, tzn. z uwagi na dobro $\mathrm{w}$ sensie soteriologicznym i politycznym, czyli dobro rozumiane jako dobrostan obywateli.

Herder proponuje połączyć praktykę filozofowania z celem politycznym w oparciu o metodę fizyki. Za przedkrytycznym Kantem odrzuca metodę matematyczną, która operuje głównie konstruktami pojęciowymi bez uzasadniania ich empirycznej prawomocności ${ }^{34}$. Fizyka zaś odnosi się do realnie istniejących obiektów i nie wychodzi od hipotez, lecz opiera się na doświadczeniu. Odpowiednikiem fizycznej metody na gruncie filozofii ma być zaproponowana przez niego subiektywna (podmiotowa) psychologia, tzn. nie tylko psychologia racjonalna w stylu psychologii Christiana Wolffa, ale przede wszystkim empiryczna, będąca częścią empirystycznej metafizyki. Herder stanowczo stwierdza, że psychologia podmiotowa nie powinna wychodzić od definicji pojęć (jak u Wolffa). Należy raczej zacząć od wskazania istotnych cech rzeczy rozpoznanych w aktach percepcji przez zmysł wewnętrzny, a następnie na drodze abstrakcji wyprowadzić $\mathrm{z}$ nich najbardziej ogólne pojęcia oraz prawa dotyczące ludzkiego bytu i działania ${ }^{35}$. Herder próbuje zatem w proponowanym modelu psychologii połączyć metodę analityczno-indukcyjną z metodą dedukcyjną opartą na sylogistycznym wnioskowaniu. Uzasadnienie prawdziwości, obiektywności pojęć nie polega tutaj na sprowadzaniu ich do ontologicznych zasad jak u Wolffa, lecz na tropieniu ich psychologicznej genezy w ludzkim podmiocie ${ }^{36}$. Stąd płynie dla Herdera

\footnotetext{
${ }^{34}$ Johann Gottfried Herder, Wie die Philosophie zum Besten, 106.

35 Tamże, 112.

${ }^{36}$ Tamże.
} 
wniosek, że logikę i filozofię moralną należy ugruntować na metafizyce tożsamej z empiryczną psychologią.

W nowej perspektywie dusza ludzka jawi się jako część psychofizycznej całości będącej wyrazem sił oraz skutków ich oddziaływania. Herder wykorzystuje w tym miejscu popularną wówczas wśród lekarzy metaforę organizmu, wskazując, że każda część całości funkcjonuje zarazem jako cel sam w sobie i jako środek służący całości. Zmiana paradygmatu filozofii dokonana dzięki wprowadzeniu do niej metody psychologii subiektywnej powinna umożliwić zbudowanie mostu między scholastycznym intelektualizmem a zdrowym rozsądkiem nastawionym na szukanie orientacji w codziennym życiu. Odnowiona filozofia ma szansę reprezentować najwyższy poziom rozwoju ludzkiego umysłu i przyczynić się do rozwoju wszystkich ludzi, tworząc podstawy powszechnego kształcenia w sensie Bildung. Celem filozofii ma być więc edukacja narodu pojętego nie w sensie etnicznym, ale w znaczeniu, jaki nadał temu pojęciu już Cyceron, czyli ogółu obywateli ${ }^{37}$. Użyteczność filozofii jest więc dwojakiego rodzaju: służy zarówno rozwojowi ludzkiego potencjału, czyli Humanität, jak i kształceniu obywateli oraz przygotowywaniu ich do aktywnego uczestnictwa w życiu publicznym. Filozofia zostaje umieszczona w centrum planowanej reformy edukacyjnej, której istotą ma być stworzenie systemu nauczania opartego nie tyle na przekazywaniu abstrakcyjnych treści, ile na rozwijaniu predyspozycji tkwiących w zdrowym rozsądku. Szkolnictwo nie ma służyć wiedzy dla niej samej, ale dawać praktyczne reguły, jak racjonalnie działać, poszerzać wiedzę o życiu. „Zamiast logiki i teorii moralności filozoficzny duch kształci ludzki byt w samodzielnym myśleniu i odczuwaniu cnoty"38.

Aby wprowadzić w życie nowy plan edukacyjny, filozofia musi najpierw wypracować kompletną koncepcję człowieka obejmującą jego wyższe i niższe władze poznawcze. Innymi słowy filozofia musi oprzeć się na nowej antropologii, która uwzględni zarówno psychologiczne, jak i przyrodniczo-geograficzne uwarunkowania ludzkiej kondycji, a przy tym historię ludzkości. Właściwe wychowanie człowieka wymaga wglądu w historyczne i kulturowe zróżnicowania, które na przestrzeni wieków określały samowiedzę antropo-

\footnotetext{
37 Tamże, 108.

38 Tamże, 122.
} 
logiczną i moralną człowieka. Filozofia jako antropologia powinna tym samym łączyć wiedzę przyrodniczą z historyczną. Podstawą wszelkiej edukacji jest bowiem uczenie ludzi autonomicznego działania i wspieranie samodzielnego myślenia, które rozumie swoje uwarunkowania i ćwiczy się w empatycznym przejmowaniu innych punktów widzenia oraz innych sposobów doświadczania siebie i rzeczywistości. Człowiek dąży do tego, by przetrwać, ale jego niezbywalną potrzebą jest również pragnienie samorozwoju, który urzeczywistnia się w procesie dziejowym. Jedynym remedium na uzdrowienie filozofii staje się, zdaniem Herdera, przekształcenie jej w antropologię: „Cała nasza filozofia staje się antropologią"

Należy przy tym pamiętać, że antropologia rozwijana przez Herdera nie ogranicza się do badania przyrodniczych i historycznych uwarunkowań człowieka, ale odwołuje się do pewnej wizji metafizycznej i koncepcji Boga, których nie będę omawiał w tym miejscu. Wspomnę tylko, że Herder zastępuje postkartezjańską ontologię substancji witalistyczną ontologią siły. Człowiek jest przejawem niepoznawalnych boskich sił rządzących całym uniwersum i może poznać tylko skutki ich oddziaływania. Ta spekulatywna zmiana optyki postrzegania świata i człowieka budzi poważne wątpliwości, jednak oferuje interesującą perspektywę badawczą, w której znikają tradycyjne podziały na duszę i ciało oraz stereotypowe klasyfikacje władz poznawczych, a w ich miejsce wkracza dynamiczna holistyczna perspektywa postrzegania człowieka i rzeczywistości. Źródłową siłą jest Bóg, który kreuje siły organizujące wszechświat. Bóg uzewnętrznia się poprzez stworzenie i na drodze okrężnej dochodzi do samopoznania. Dusza ludzka podobnie jak Bóg jest siłą, która poznaje siebie poprzez materialną stronę swojego istnienia, czyli poprzez ciało. Dusza i ciało są jedynie różnymi przejawami tej samej siły ${ }^{40}$. Bóg poznaje świat i siebie samego jedną nieskończoną myślą, natomiast ludzki rozum potrzebuje okrężnej drogi przez ciało. Nie istnieją dwa oddzielne rodzaje przyczynowości, tylko dwa różne aspekty tego samego porządku oddziaływania sił. Elementy duchowe i fizyczne ludzkiej aktywności przenikają się wzajemnie, dlatego nie ma sensu oddzielać sztucznie zmysłów od

\footnotetext{
39 Tamże, 134.

${ }^{40}$ Por. szczegółowe omówienie tej problematyki w: Marion Heinz, Sensualistischer Idealismus. Untersuchungen zur Erkenntnistheorie des jungen Herder (1763-1778) (Hamburg: Felix Meiner Verlag, 1994), 177-182.
} 
intelektu. Czynności intelektualne są przejawem siły czy władzy wytwarzania przedstawień bazującej na tym, czego dostarczają duszy zmysły. To, co tradycyjnie przedstawia się jako ciało i duszę, stanowi w istocie organiczny system samozwrotnych oddziaływań, w którym zmysły dostarczają wrażeń i w ten sposób kształtują duszę, a siła myślenia porządkuje je, profilując jednocześnie same zmysły. Herder zwraca m.in. uwagę na fakt, że wczesne impulsy (Anstöße) determinują naszą psychikę na całe życie ${ }^{41}$. Jednakże np. przyswajanie języka nie tylko służy funkcjom ekspresyjnym i komunikacyjnym, ale także odgrywa niebagatelną rolę w procesie formowania percepcji. Dusza nie stanowi więc odrębnej substancji, autonomicznej dziedziny wewnętrznej aktywności, ponieważ doświadczamy ją zawsze jako duszę ucieleśnioną, której podstawową zasadą jest pierwotne, zmysłowe, a zatem mętne, choć apodyktycznie pewne odczucie własnego bytu. W miarę rozwoju osobowego to odczucie ulega pojęciowej krystalizacji, ale nigdy nie zostaje w pełni wyeksplikowane.

Nie można poznać duszy, nie uwzględniając przyrodniczych, kulturowych i środowiskowych uwarunkowań, w jakich przyszło jej żyć. Każda psychika stanowi przejaw niezwykle plastycznego potencjału ludzkich predyspozycji i inklinacji, dlatego nigdy nie uda się stworzyć niepodważalnego systemu powszechnych i koniecznych pojęć, które wyjaśniałyby naturę człowieka. Stanowisko Herdera odnośnie do ludzkiej natury unika więc esencjalizmu i zbliża się pod tym względem do Nietzscheańsko-Gehlenowskiego ujęcia człowieka jako „nieustalonego zwierzęcia”.

\section{Antropologia i fizjologia}

Tworząc swój projekt antropologicznie ufundowanej filozofii, Herder inspirował się odkryciami współczesnej mu medycyny. Szczególny wpływ wywarły na niego prace getyńskiego fizjologa Albrechta von Hallera, który zrewolucjonizował ówczesną wiedzę o systemie nerwowym, wprowadzając rozróżnienie na pobudliwość mięśniową i nerwową wrażliwość. W trakcie

${ }^{41}$ Tamże, 178. 
eksperymentów na zwierzętach, również wiwisekcji, Haller zaobserwował, że pobudliwość mięśni zostaje zachowana, tzn. dochodzi do skurczów i rozkurczów nawet wówczas, gdy odetnie się ich połączenia z nerwami, i że dzieje się tak również przez jakiś czas post mortem ${ }^{42}$. To skłoniło go do wysunięcia koncepcji, że wrażliwość jest ograniczona do systemu nerwowego, a znaczna część organizmu, np. ścięgna, reaguje bez jego pośrednictwa i jest niewrażliwa. Choć sam był osobą religijną i wierzył, że ludzki umysł obdarzony jest zdolnością poznania, której celem jest celebracja boskiego stworzenia, jego teoria zmieniła sposób postrzegania pewnych istotnych problemów epistemologicznych. Po pierwsze, teoria ta nasuwała wniosek, że psychika jest bardziej związana z ciałem, tj. z systemem nerwowym, niż sądzono wcześniej. Jeśli ktoś zaakceptował ten wniosek, musiał przyznać, że procesy psychiczne odbywają się w horyzoncie wyznaczonym przez system nerwowy ludzkiego ciała. To zaś nieuchronnie prowadziło do konkluzji, że dusza nie może oddziaływać na całe ciało za pośrednictwem nerwów. Może być ona przyczyną sprawczą intencjonalnych ruchów, jednak nie ma wpływu na ruchy mimowolne. Podobne wnioski wyprowadził m.in. Julien Ofrey de La Mettrie, z którym Haller polemizował do końca życia, a nawet oskarżył go o plagiat i wyprowadzanie fałszywych wniosków z niewinnej teorii. Herder, odwołując się do Hallera, próbował uniknąć wskazanych problemów za pośrednictwem wspomnianej wcześniej witalistycznej koncepcji duszy. Z jednej strony przyjął za Hallerem, że istnieją dwa różne porządki cielesności: pobudliwość mięśni i wrażliwość mózgu, z drugiej strony założył, że stanowią one przejawy jednej i tej samej, pierwotnej siły fundującej ludzką cielesność. Oczywiście, zgodnie z przyjętą przez siebie postawą agnostycyzmu powątpiewał równocześnie, abyśmy mogli kiedykolwiek zbadać tory wrażliwości i pobudliwości do punktu, w którym łączą się one za sprawą leżącej u ich podłoża formy energii. W Myślach o filozofii dziejów Herder odwołuje się w tym kontekście wprost do Hallera:

${ }^{42}$ Por. Hubert Steinke, Irritating Experiments: Haller's Concept and the European Controversy on Irritability and Sensibility, 1750-1790 (Amsterdam-New York: Rodopi, 2005). 
Nieśmiertelny Haller rozróżniał z taką dokładnością siły, przejawiające się fizjologicznie w ciele zwierzęcym, a mianowicie elastyczność włókien, pobudliwość mięśni, a wreszcie wrażliwość ustroju nerwowego, że jego twierdzenia [...] powinny nawet znaleźć jak najszersze zastosowanie w fizjologicznej nauce o duszy nie tylko człowieka, ale i innych stworzeń. Pozostawiam na uboczu zagadnienie, czy te trzy niewątpliwie tak różne zjawiska nie stanowią w istocie rzeczy jednej i tej samej siły, która objawia się inaczej we włóknach, inaczej w mięśniach, a inaczej w systemie nerwowym. Trudno w to wątpić, gdyż w przyrodzie wszystko ze sobą się łączy, te zaś trzy siły wiążą się w żywym ciele tak ściśle i w tak wieloraki sposób. Elastyczność i pobudliwość graniczą ze sobą, podobnie jak graniczą ze sobą włókna i mięśnie. I tak jak mięśnie stanowią tylko kunsztowny splot włókien, tak pobudliwość nie jest prawdopodobnie niczym innym, jak tylko jakąś nieskończenie, w wewnętrzny sposób wzmożoną elastycznością, która w tym ograniczonym splocie wielu części wznosi się z martwego czucia właściwego włóknu na pierwszy szczebel samopobudzenia się zwierzęcia. Wrażliwość systemu nerwowego będzie zatem trzecią wyższą postacią tej samej siły, rezultatem wszystkich poprzednich sił organicznych, ponieważ całe krążenie krwi i wszystkie temu krążeniu podporządkowane naczynia zdają się być potrzebne do zwilżania mózgu - jako korzenia nerwów - tym delikatnym sokiem, który jako medium istnienia wrażeń tak bardzo wznosi się ponad siły mięśni i włókien ${ }^{43}$.

Według Herdera jedynym dostępnym sposobem poznania tych zależności jest poszukiwanie analogii w świecie zwierząt i roślin. Zaobserwowane zbieżności mogą ułatwić zrozumienie korelacji między ciałem i duszą będącymi przejawami tej samej boskiej siły. Wyłącznie introspekcyjne badanie władz umysłowych prowadzi do ślepej uliczki dualizmu psycho-fizycznego. Rozum jest do tego stopnia ściśle związany z ciałem i z zapośredniczonym przez nie światem, że jedyną drogą do samopoznania pozostaje dla niego badanie własnej zmysłowości oraz zewnętrznego „kręgu życia”. Człowiek poznaje siebie poprzez skutki własnych działań i ekspresji skierowanych ku innym. Czysta introspekcja zamyka go natomiast $\mathrm{w}$ wyobrażeniowym świecie monologicznych halucynacji. Antropologia powinna zatem rozwijać się na podstawie metody nastawionej na poszukiwanie podobieństw między królestwem roślin, zwierząt i ludzi.

\footnotetext{
${ }^{43}$ Johann Gottfried Herder, Myśli o filozofii dziejów, 93-94.
} 
Herder chce uzupełnić poznanie dyskursywne, oparte na języku, poznaniem afektywno-intuicyjnym, które mimo braku jasności i wyraźności pojęciowej odgrywa istotną rolę w procesach poznawczych. Najważniejszym środkiem tego rodzaju intuicyjno-dyskursywnego poznania jest metoda myślenia analogicznego (od grec. aneulogos - „bez słów”). Podobne narzędzie stosował już Platon, opisując problemy, które wykraczały poza pojęciowe kompetencje dialektyki, jednak Herder nawiązuje przede wszystkim do postępowania badawczego wykorzystywanego w komparatystycznej anatomii, zoologii i fizjologii. Ówcześni badacze ustalający struktury podobieństwa, taksonomiczne podziały, żywili przekonanie, że porównanie człowieka ze zwierzętami (a w pewnej mierze również z roślinami) może pomóc wyjaśnić mechanizm ludzkiego organu niemożliwy do zbadania w sposób tradycyjny. Wśród zwierząt można napotkać podobne funkcje organów jak u człowieka, tyle że działające w prostszy sposób i ukazujące rozmaite warianty tego samego podstawowego wzorca. Tego rodzaju badania doprowadziły do stworzenia fizjo-teleologicznego modelu natury jako łańcucha bytów, który stanowi ekspresję boskich myśli, a którego pierwszym i ostatnim elementem jest człowiek. Herder radykalizuje te idee, utrzymując, że należy opisywać człowieka, jego rozum i świadomość, jego człowieczeństwo na podstawie podobieństw z animalną pobudliwością i wrażliwością nerwową. Przed Herderem zachowywano tradycyjny podział pracy między historią naturalną (zwłaszcza medycyną) i filozofią, która miała monopol na wyjaśnianie specyficznie ludzkich atrybutów. Stał się on problematyczny już pod koniec XVII wieku po opublikowaniu przez Edwarda Tysona rozprawy Orang-outan, sive Homo sylvestris, or The Anatomy of a Pygmic Compared with That of a Monkey (1699), która ukazywała trudności w znalezieniu różnic między orangutanem a człowiekiem na płaszczyźnie czysto anatomicznej i fizjologicznej. Herder nawiązuje do tej rozprawy, wskazując że nie ma istotnych fizycznych rozbieżności między nami a pozostałymi naczelnymi. Podobnie jak one jesteśmy zwierzętami, jesteśmy jednak inni w aspekcie fizjologicznym: mamy biologiczne deficyty, nie przejawiamy dostosowania do środowiska, nie mamy organów ataku i ucieczki, nasze instynkty są zredukowane. Dlatego powinniśmy poszukiwać analogii ze zwierzętami i roślinami, aby w ten sposób uzmysłowić sobie sens posiadanych przez nas funkcji i organów. Na przykład rośliny mogą rzucić światło na nasze najbardziej elementarne funkcje odżywiania i repro- 
dukcji. Roślina realizuje te funkcje w sposób doskonały, niejako wyczerpuje się w nich, nie zależąc od delikatnego i podatnego na uszkodzenia organu, jakim jest ludzki żołądek. Podobnie zimnokrwiste zwierzęta urzeczywistniły wysoce rozwiniętą pobudliwość, która działa nawet po odcięciu ich organów i pozwala im na autoregenerację - zdolność, którą zatraciły bardziej wrażliwe zwierzęta ciepłokrwiste, $\mathrm{w}$ tym człowiek.

Istotę poznania przez analogię dobrze wyraża spójnik ,jak”. W poznaniu dyskursywnym wyrażonym za pomocą sądów predykatywnych najważniejsza pozostaje spójka ,jest”, wskazująca na tożsamość, na subsumcję danego zjawiska, procesu pod ogólną kategorię lub prawo. Natomiast „jak” implikuje równocześnie tożsamość i różnicę. Dzięki temu analogiczne poznanie unika redukcji partykularności, czyli podporządkowywania tego, co jednostkowe, ogólnej abstrakcji. Nie chodzi w nim o indukcyjną generalizację, lecz o zdolność uchwytywania relacji podobieństwa pomiędzy heterogenicznymi elementami. Dopiero rozpoznanie relacji, a nie identyfikacja samego elementu decyduje o wartości poznania. Herder podaje w tym kontekście przykład z zoologii. Obserwując formę organiczną ryby przez pryzmat formy ptaka, rozpoznajemy podobieństwa i różnice między nimi, uczymy się dostrzegać sposób, w jaki ich struktura anatomiczna odzwierciedla środowisko, i zaczynamy chwytać jej funkcjonalny sens ${ }^{44}$. Dystynktywne cechy ryby możemy rozpoznać tylko na drodze analogii z innymi formami organicznymi, odnosząc je wszystkie do otoczenia, w jakim żyją. Dopiero wtedy możemy rozpocząć poszukiwanie praw, które wyjaśniają je przyczynowo. Porównując różne gatunki, poznajemy dynamiczne kontinuum obfitujące w zróżnicowania i podobieństwa. Na końcu docieramy do głównej prototypowej formy, która daje początek wszystkim wariacjom i przekształceniom. Główna forma (Hauptform), czy jak później będzie pisał Johann Wolfgang Goethe "praforma”, nie jest konkretnym obiektem, lecz niedostępną bezpośrednio dla poznania głęboką strukturą, która przejawia się w nieskończonej ilości wariantów. „Otóż nie da się zaprzeczyć, mimo całej różnorodności istot żyjących na ziemi, że wszędzie zdaje się panować pewna jednostajność budowy, jakby jedna główna forma powtarzająca się

${ }^{44}$ Tamże, 81-82. 
w najbogatszej różnorodności” ${ }^{45}$. Uchwycenie głębokiej struktury, „głównej formy" nie polega na pojęciowej abstrakcji, lecz na intuicyjnym wglądzie, do którego prowadzą ćwiczenia w rozpoznawaniu analogii.

Zmiana perspektywy badawczej za sprawą fizjologii i metody myślenia analogicznego umożliwiła Herderowi sformułowanie nowej koncepcji człowieka, nowej wizji ludzkiej duszy. Fizjologiczne badania Hallera utwierdziły go w przekonaniu, że nie da się zlokalizować takich funkcji poznawczych jak wyobraźnia, rozum, pamięć, władza pożądania etc. w jakimś określonym regionie mózgu czy systemu nerwowego. Obawa dotycząca skuteczności takich poszukiwań umocniła go $\mathrm{z}$ kolei w przeświadczeniu o trafności jego własnej holistycznej i witalistycznej koncepcji człowieka. Dusza i ciało stanowią jedność, są organicznym systemem różnie ukierunkowanych sił, które łączą się w niezwykle plastyczną całość domagającą się nieustannego kształtowania, dyscypliny i pracy. Przetrwanie człowieka w naturze, do której nie jest instynktownie przystosowany, stanowi więc dla niego zadanie, a nie dany z góry horyzont możliwości, jak w przypadku zwierząt. Ludzka duchowość, czy też tzw. czysty intelekt, powstaje w wyniku transformacji zmysłowości i nigdy nawet w swoich rzekomo najbardziej abstrakcyjnych przejawach nie traci z nią łączności.

Sensualizm Herdera reprezentuje wariant klasycznego empiryzmu, jednak myśliciel odrzuca stanowiska zarówno subiektywistyczne, jak i sceptyczne. Witalistyczna metafizyka, która leży u podłoża jego teorii poznania, pozwala mu przyjąć założenie, że choć procesy poznawcze zachodzące w człowieku są wprawdzie wysoce niedoskonałe, narażone na błędy i iluzje, to stanowią przejaw obiektywnych sił działających w całym uniwersum.

\section{Antropologia jako filozofia dziejów i języka}

Herder przy różnych okazjach powtarza, że najważniejszym medium, które łączy człowieka ze światem i poprzez które konstytuują się ludzkie zdolności poznawcze, jest język. „Żaden naród nie posiada idei, na ozna-

45 Tamże, 77. 
czenie której nie posiada słowa; najżywsza naoczność pozostaje ciemnym uczuciem, dopóki dusza nie znajdzie pewnej cechy i nie wcieli jej jej przy pomocy słowa w pamięć, we wspomnienie, w intelekt, a w końcu w intelekt całej ludzkości, czyli w tradycję. Czysty rozum bez mowy to utopia na ziemi" ${ }^{46}$.

Herder zgodziłby się z Friedrichem Nietzschem, że nasza wiedza jest perspektywiczna, uzależniona od metafor i podporządkowana imperatywom przetrwania, ale nie podzieliłby jego sceptycyzmu wobec poznania naukowego. Rozum dysponuje jedynie konstrukcjami językowymi, nie istnieją pojęcia a apriori, ale to bynajmniej nie oznacza, że poznanie jest wyłącznie subiektywnym wytworem, ponieważ język wyrasta ze źródłowego, zmysłowego doświadczenia świata, dokonuje niejako translacji „milczącej, sensualnej mowy" rzeczywistości zewnętrznej na pojęcia dostosowane do wymogów aparatu poznawczego człowieka. Przekład wrażeń pochodzących z zewnętrznego świata na język podmiotu nie oznacza jednak translacji między dwoma różnymi językami, lecz transpozycję treści pochodzących z porządku o większej złożoności (świat) na porządek o mniejszej złożoności (aparat poznawczy podmiotu).

Stanowisko Herdera nie jest również pozycją naiwnego realizmu, ponieważ witalistyczne założenia nie pozwalają mu przyjąć tezy o możliwości bezpośredniego doświadczenia realnie istniejących obiektów. Herder podkreśla, że nie mamy ani pewnej wiedzy o świecie zewnętrznym, ani bezpośredniego dostępu do ukrytych sił kształtujących nasze wnętrze. Jednak wrażenia, afekty i język, będące przejawem niepoznawalnych sił, tworzą ze światem więzy, które gwarantują nam przeżycie i orientację w otoczeniu. Sam fakt istnienia i rozwoju świadczy o trafności naszej aktywności poznawczej. Człowiek jest szczególnym rodzajem instrumentu, na którym gra natura, a my wybrzmiewamy w mniejszej lub większej harmonii z tym, w jaki sposób naturalne zjawiska „uderzają" w nasze poznawcze struny.

Herderowski projekt antropologizacji filozofii niewątpliwie wyróżnia się naciskiem kładzionym na rolę języka w formowaniu się człowieczeństwa, jego poznania, kultury i dziejów. To właśnie za pośrednictwem mowy człowiek porządkuje chaos i nadmiar nieprzefiltrowanych przez instynkty

${ }^{46}$ Tamże, 397. 
wrażeń w linearny ciąg idei, uzyskuje samoświadomość, działa, gromadzi i przekazuje dalej swoje doświadczenia, tworząc wspólnotowe więzy, których manifestacją jest naród. Język i rozumność to dwie strony tej samej monety. Nie istnieje powszechny rozum, tak jak nie ma uniwersalnego języka. Rozum ucieleśnia się bowiem poprzez język w rozmaitych formach współokreślanych przez tradycję danego narodu, jego historyczne przemiany i zewnętrzne, środowiskowe uwarunkowania. Aby zrozumieć człowieka, jego racjonalność, musimy zbadać ewolucję jego języka w świetle historycznych i kulturowych przemian całych narodów.

Herderowska filozofia języka nieuchronnie łączy się zatem z filozofią dziejów. Myśliciel unika powszechnego w jego czasach teleologicznego ujęcia historii. Dzieje ludzkości nie realizują nadrzędnego jednolitego celu, chociaż można w nich intuicyjnie przeczuć niepoznawalny zamysł boskiej opatrzności. Według Herdera należy porzucić kauzalną analizę historii, ponieważ zniekształca ona ich sens pod kątem wyznaczonym przez system wartości, ukrytych przesądów i oczekiwań historyka zanurzonego w swojej teraźniejszości. Autor Auch eine Philosophie der Geschichte zur Bildung der Menschheit poświęca wiele uwagi krytyce tradycyjnych koncepcji historiozoficznych, nie mamy tutaj jednak dość miejsca, żeby rozwijać ten skądinąd dość dobrze znany wątek. W telegraficznym skrócie można powiedzieć, że Herder próbuje zastosować w swojej praktyce pisarskiej słynne spostrzeżenie Arystotelesa, że poezja jest bliższa prawdy niż historia. Zgodnie z tą intuicją za najlepszych historyków uważa on poetów-dziejopisarzy obdarzonych elastyczną wyobraźnią, rozwiniętą zdolnością empatycznego wczuwania się w inne światy historyczne i bezstronnością, która zabrania im oceniać inne kultury według standardów przyjętych w ich własnej epoce. W tym właśnie duchu Herder pojmował swoje historiozoficzne przedsięwzięcia, pisząc, że w istocie nie bada dziejów, tylko opowiada historie, szuka w nich analogii, próbuje je zrozumieć, mając świadomość, że jego opowieść jest zawsze subiektywną narracją, która jednak nie porzuca z tego powodu roszczenia do poznania prawdy. W każdej epoce i kulturze inaczej realizuje się potencjał człowieczeństwa, dzieje nie zmierzają bowiem do jednego celu, nie ma w nich ciągłości, która mogłaby sugerować działanie jakiejś nadrzędnej logiki poza niezbywalną dla człowieka potrzebą urzeczywistnienia ukrytych w nim możliwości i osiągnięcia przynajmniej tymczasowego stanu szczęścia 
i wolności. Postęp wiedzy nie implikuje z konieczności rozwoju moralnego ani szczęścia ludzkości, pociąga natomiast za sobą deficyty, które można sobie unaocznić, studiując dzieje różnych kultur.

\section{Podsumowanie}

Artykuł miał na celu przedstawić główne założenia Herderowskiego projektu przekształcenia filozofii $\mathrm{w}$ antropologię oraz odpowiedzieć na pytanie, czy projekt ten mieści się w ramach pojęciowych wyznaczonych przez metafilozoficzną definicję antropologii jako dyscypliny antagonistycznej wobec filozofii dziejów i metafizyki, którą przedstawił Odo Marquard. Przedstawione analizy pokazują wyraźnie, że twórczość Herdera wymyka tego rodzaju klasyfikacjom. Wprawdzie jego filozofia dziejów odbiega od ówczesnych koncepcji historiozoficznych, jednak bez wątpienia ściśle łączy przekonanie o historycznym charakterze ludzkiej egzystencji $\mathrm{z}$ antropologicznym spojrzeniem na jej naturę. Podobnie krytyczny stosunek Herdera do tzw. szkolnej metafizyki nie oznacza bynajmniej rezygnacji z metafizycznego wymiaru zaproponowanej przez niego antropologii. Przeczy temu obecna w niej witalistyczna metafizyka niepoznawalnych sił natury, odwołująca się do systemu Barucha Spinozy i Gottfrieda Wilhelma Leibniza.

Z powodu nieprzystawalności antropologii Herdera do modelu Marquardowskiego nie powinniśmy wyciągać wniosku, że jego projekt nie mieści się w linii rozwojowej prowadzącej bezpośrednio do współczesnej antropologii filozoficznej. Za uznaniem go za prekursora klasyków tej dyscypliny przemawia to, że w centrum rozważań filozoficznych umieścił on empiryczną refleksję nad kondycją człowieka, skierował swoje badania ku sferze życia codziennego i jego kulturowych uwarunkowań, a wreszcie konsekwentnie uwzględniał wymiar zmienności, skończoności i kontyngencji jako istotny składnik ludzkiej egzystencji. Niewątpliwie w wielu szczegółowych ustaleniach antycypował późniejsze koncepcje antropologiczne, nie odrzucał przy tym - jak pokazaliśmy - wartości nauk przyrodniczych, nie był więc, wbrew późniejszym fałszywym interpretacjom, jedy- 
nie sentymentalnym irracjonalnym poetą-myślicielem, który nie zasługuje na miano prawdziwego filozofa. Nie bez znaczenia jest również fakt, że powoływali się na niego główni animatorzy antropologii filozoficznej, jak Helmuth Plessner czy Arnold Gehlen, który w swojej programowej pracy stwierdził: „antropologia filozoficzna od wystąpienia Herdera nie uczyniła żadnego kroku naprzód, a jego ujęcie w ogólnych zarysach prezentuje stanowisko, które chciałbym rozwinąć przy użyciu środków współczesnej nauki. Ujęcie to nie musi robić żadnego kroku naprzód, ponieważ w istocie wyraża prawdę" ${ }^{47}$.

\section{Bibliografia}

Böhme Gernot. 1998. „Immanuela Kanta antropologia w ujęciu pragmatycznym”, w: Böhme Gernot, Antropologia filozoficzna. Ujęcie pragmatyczne, red. Stanisław Czerniak, tłum. Piotr Domański, 231-244. Warszawa: Wydawnictwo IFiS PAN.

Gehlen Arnold. 2017. Człowiek. Jego natura i stanowisko w świecie, tłum. Rafał Michalski, Jarosław Rolewski. Toruń: Wydawnictwo Naukowe UMK.

Herder Johann Gottfried. 1962. Myśli o filozofii dziejów, tłum. Józef Gałecki. T. 1. Warszawa: PWN.

Herder Johann Gottfried. 1985. Versuch über Sein. W: Herder Johann Gottfried, Werke, t. 1, Frühe Schriften, 1764-1772, 9-29. Frankfurt am Main: Dt. Klassiker Verlag.

Herder Johann Gottfried. 1985. Wie die Philosophie zum Besten des Volks allgemeiner und nützlicher werden kann. W: Herder Johann Gottfried, Werke. T. 1, Frühe Schriften, 1764-1772, 101-134. Frankfurt am Main: Dt. Klassiker Verlag.

Herder Johann Gottfried. 1987. „Rozprawa o pochodzeniu języka”. W: idem, Wybór pism, tłum. Barbara Płaczkowska, 59-175. Wrocław: Zakład Narodowy im. Ossolińskich.

Istota żywa jako podmiot: Wybór pism Jakoba Johannesa von Uexkülla. 1998. Red. Aldona Pobojewska. Łódź: Studio Wydawnicze KARTA.

Markowski Paweł. 2013. Polityka wrażliwości. Kraków: Universitas.

Marquard Odo. 1973. Schwierigkeiten mit der Geschichtsphilosophie. Frankfurt am Main: Suhrkamp.

${ }^{47}$ Arnold Gehlen, Człowiek. Jego natura i stanowisko w świecie, tłum. Rafał Michalski, Jarosław Rolewski (Toruń: Wydawnictwo Naukowe UMK, 2017), 130. 
Marquard Odo. 1994. Apologia przypadkowości, tłum. Krystyna Krzemieniowa. Warszawa: Terminus.

Paczkowska-Łagowska Elżbieta. 2000. Logos życia. Filozofia hermeneutyczna w kręgu Wilhelma Diltheya. Gdańsk: Słowo/obraz terytoria.

Steinke Hubert. 2005. Irritating Experiments: Haller's Concept and the European Controversy on Irritability and Sensibility, 1750-1790. Amsterdam-New York: Rodopi.

Żelazny Mirosław. 2000. Heglowska filozofia ducha. Toruń: Wydawnictwo Naukowe UMK.

Żelazny Mirosław. 2001. Idea wolności w filozofii Kanta. Toruń: Wydawnictwo Rolewski.

\section{Abstract}

\section{Anthropological turn in the philosophy of the Enlightenment - Johann Gottfried Herder}

The article critically examines a description of the genesis of the philosophical anthropology proposed by Odo Marquard. The German philosopher describes a combination of ideological conditions which in the Age of the Enlightenment led to the emergence of a unique way of practicing philosophy as anthropology. In his analyzes, however, he omits Herder's work. The arguments included in the first section of the article are aimed at proving the inadequacy of such an interpretation. In the other sections of the text, I reconstruct the most important assumptions of Herder's program of transforming philosophy into anthropology. These analyzes also provide arguments that are polemical to Marquard's interpretation.

Keywords: philosophical anthropology; philosophy of history; Herder; enlightenment; nature; language; history; physiology.

\section{Streszczenie}

\section{Antropologiczny zwrot w filozofii oświecenia - Johann Gottfried Herder}

Artykuł poddaje krytycznej rewizji opis genezy antropologii filozoficznej, jaką zaproponował Odo Marquard. Niemiecki filozof opisuje splot uwarunkowań ideowych, które w epoce oświecenia doprowadziły do pojawienia się szczególnego 
sposobu uprawiania filozofii jako antropologii. W swoich analizach pomija jednak twórczość Herdera. Wywody pierwszej części artykułu mają na celu wykazanie nietrafności takiej interpretacji. W pozostałych częściach tekstu rekonstruuję najważniejsze założenia Herderowskiego programu przekształcenia filozofii $\mathrm{w}$ antropologię. Analizy te dostarczają jednocześnie argumenty polemiczne wobec interpretacji Marquarda.

Słowa klucze: antropologia filozoficzna; filozofia dziejów; Herder; oświecenie; natura; język; historia; fizjologia. 